\title{
Temporal and spatial patterns in the diet of northern fulmars Fulmarus glacialis in the Canadian High Arctic
}

\author{
M. L. Mallory ${ }^{1, *}$, N. J. Karnovsky ${ }^{2}$, A. J. Gaston ${ }^{3}$, K. A. Hobson ${ }^{4}$, J. F. Provencher ${ }^{5}$, \\ M. R. Forbes ${ }^{6}$, G. L. Hunt Jr. ${ }^{7}$, T. Byers ${ }^{8}$, T. A. Dick ${ }^{9}$ \\ ${ }^{1}$ Canadian Wildlife Service, Box 1714, Iqaluit, Nunavut X0A 0H0, Canada \\ ${ }^{2}$ Department of Biology, Pomona College, 175 W. 6th St., Claremont, California 91711, USA \\ ${ }^{3}$ National Wildlife Research Centre, Environment Canada, Carleton University, Ottawa, Ontario K1A 0H3, Canada \\ ${ }^{4}$ Environment Canada, 11 Innovation Blvd., Saskatoon, Saskatchewan SYN 3H5, Canada \\ ${ }^{5}$ Department of Biology, University of Victoria, Victoria, British Columbia V8W 3N5, Canada \\ ${ }^{6}$ Department of Biology, Carleton University, Ottawa, Ontario K1S 5B6, Canada \\ ${ }^{7}$ Department of Ecology and Evolutionary Biology, University of California - Irvine, Irvine, California 92697, USA \\ ${ }^{8}$ Byers Environmental Studies, Box 1049, Teulon, Manitoba R0C 3B0, Canada \\ ${ }^{9}$ Department of Zoology, University of Manitoba, Winnipeg, Manitoba R3T 2N2, Canada
}

\begin{abstract}
The northern fulmar Fulmarus glacialis is a medium-sized seabird with a broad, circumpolar range in the northern hemisphere, and is the only petrel that inhabits the High Arctic. We used stomach analysis and stable isotopes $\left(\delta^{15} \mathrm{~N}, \delta^{13} \mathrm{C}\right)$ of muscles to examine the diet of 179 fulmars during the breeding season at 4 locations in Arctic Canada, to compare diet to those from studies conducted in these regions $>2$ decades earlier. Across sampling locations, cephalopods, polychaetes and crustaceans dominated dietary remains in fulmars, although there was some regional variation. Both stable isotopes and stomach dissections showed that a seasonal shift in diet occurred in May, after which fulmars fed at a higher trophic level, suggesting a difference in winter/migration diet and breeding season diet. After migration, fulmar digestive organs decreased markedly in size, and by the time chicks were hatching, these organs were still 17 to $39 \%$ smaller than their size when birds arrived at the colony. Despite ongoing changes in the marine environment in much of the Arctic due to global warming, recent fulmar diet samples were similar to samples collected in the 1970s and 1980s, except that a higher proportion of recent collections contained fish.
\end{abstract}

KEY WORDS: Arctic $\cdot$ Cephalopod $\cdot$ Crustacean $\cdot$ Procellariiformes $\cdot$ Reproduction

Resale or republication not permitted without written consent of the publisher

\section{INTRODUCTION}

Invertebrate and fish fauna vary across oceanographic zones in the North Atlantic in response to differing oceanographic conditions, often on small geographic scales (e.g. Karnovsky et al. 2003). Many marine birds are generalist predators that exploit invertebrates and fish (e.g. Woo et al. 2008). Consequently, monitoring the diet of marine birds provides a measure of the diversity and availability of different types of organisms in marine food webs and allows detection of shifts in food webs due to changes in oceanographic conditions (e.g. Gaston et al. 2003, Frederiksen et al. 2004, 2006).

In the North Atlantic, the northern fulmar Fulmarus glacialis is the only Procellariiform seabird (petrel) found in Boreal, Low Arctic and High Arctic oceanographic zones (Salomonsen 1965, Hatch \& Nettleship 1998). It feeds on zooplankton, cephalopods, fish and carrion across its range in Boreal and Low Arctic waters (Furness \& Todd 1984, Hamer et al. 1997, Phillips et al. 1999, Garthe et al. 2004). Relatively less is known about 
fulmar diet in the High Arctic, although it appears to rely more on invertebrates in this region, particularly early in the breeding season, than farther south (Hatch \& Nettleship 1998, Mallory 2006).

We examined the diet of fulmars at several locations in the Canadian High Arctic. This region is experiencing environmental changes, including less extensive and thinner sea ice cover, earlier ice breakup, later ice formation and in some cases warmer sea surface temperatures (ACIA 2005). Most High Arctic marine birds use ice edges, leads and polynyas as important foraging locations because these sites are often highly productive and provide the only open water areas where prey are accessible (Brown \& Nettleship 1981, Stirling 1997). In fact, in the Canadian Arctic, most polynyas and recurrent ice leads have been identified as key marine habitat sites for migratory birds (Mallory \& Fontaine 2004). Thus, long-term changes in marine environmental conditions may influence the timing and availability of prey for breeding marine birds. For example, Gaston et al. (2003) found that the diet of thick-billed murres Uria lomvia at one Arctic colony switched from ice-associated Arctic cod Boreogadus saida to warmer-water capelin Mallotus villosus over a 20 yr period. Such changes in marine food webs could potentially influence reproduction of marine birds through changes in prey availability or diet quality. Consequently, our study sought to: (1) establish a baseline of dietary information for fulmars at locations where this had not been investigated previously; (2) compare diet of fulmars at sites where there was an earlier baseline (e.g. Bradstreet 1976); and (3) investigate whether there are seasonal changes in the diet of High Arctic fulmars as suggested by Hatch \& Nettleship (1998), and recently demonstrated for Alaskan fulmars (Wang et al. 2009). We also used 3 techniques to assess fulmar diet at different temporal scales: size of digestive organs (an index of foraging effort or shifts in types of food consumed; e.g. Ankney 1977); stable isotopes of carbon and nitrogen (indices of diet over weeks, months, or years, depending on the tissue analysed; Hobson 1993); and stomach content analysis (remains of the most recently consumed food).

\section{MATERIALS AND METHODS}

Our analysis of fulmar diet in the Canadian High Arctic was based on samples of birds collected at 4 different locations in 3 separate studies (Fig. 1). We col-

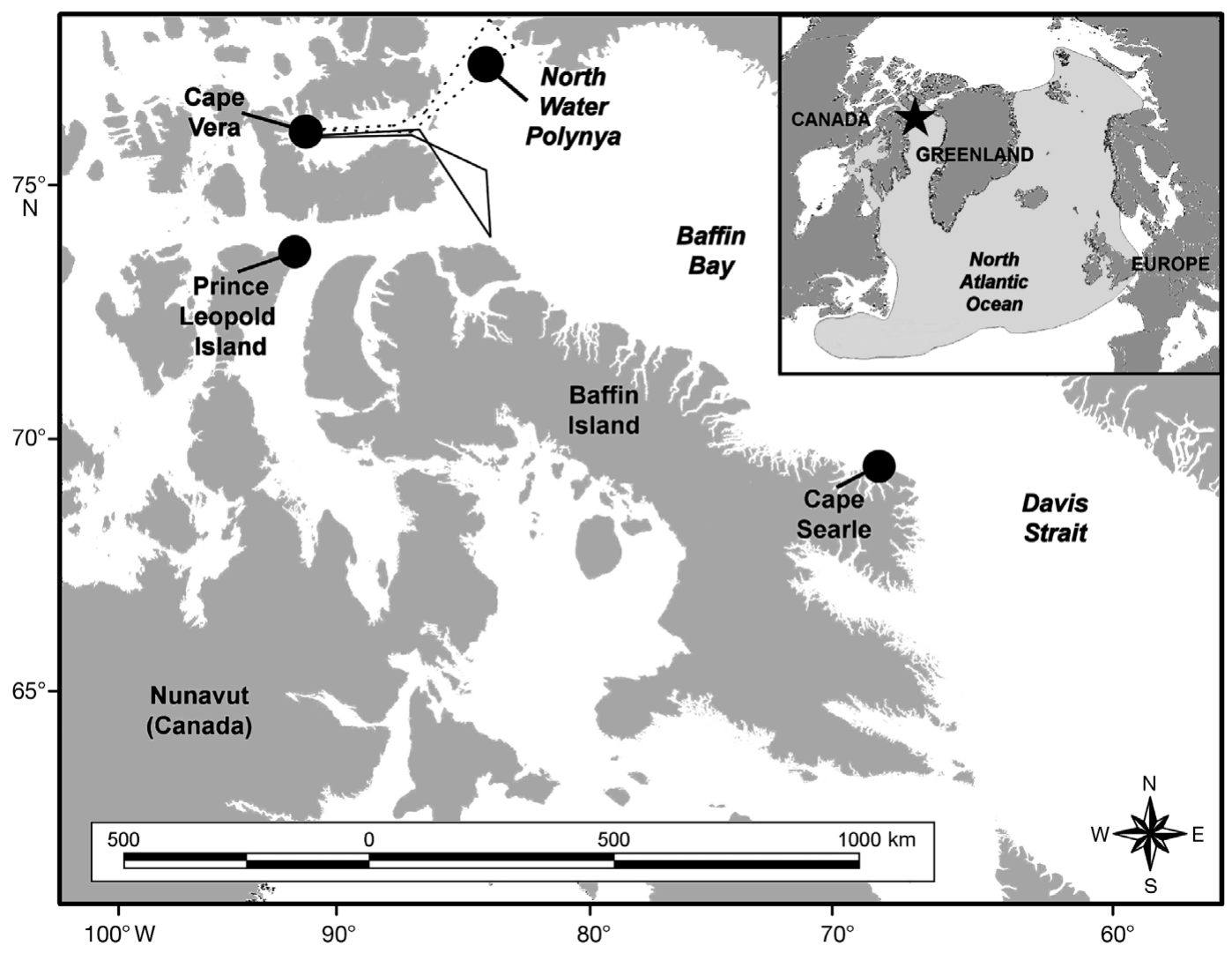

Fig. 1. Northern fulmars were sampled for dietary analyses at 4 locations spread across $10^{\circ}$ latitude in the High Arctic oceanographic zone of the Canadian Arctic. The dotted and solid lines leaving and returning to the Cape Vera field site depict 2 foraging trips of 2 fulmars equipped with satellite transmitters in July 2004 (Mallory et al. 2008b). The gray area on the inset map is the range of northern fulmars in the North Atlantic Ocean 
lected 35 fulmars at sea during May to July 1998 and August to September 1999 through the North Water Polynya (NOW) Project in the waters near $76^{\circ} 50^{\prime} \mathrm{N}$, $74^{\circ} 20^{\prime} \mathrm{W}$ (Karnovsky et al. 2008). We also collected 119 fulmars as they were returning to the breeding colony during May to August of 2003 to 2005 as part of the Cape Vera Project, at $76^{\circ} 15^{\prime} \mathrm{N}, 89^{\circ} 15^{\prime} \mathrm{W}$; for these birds, the breeding status (breeding, non- or failed breeding) was known through behavioral observations or dissection (Mallory \& Forbes 2005, 2007). In the High Arctic, fulmars begin to attend their colonies in May, lay their eggs in early June and incubate until late July, and then rear chicks through August into early September (Hatch \& Nettleship 1998, Mallory \& Forbes 2007). We also collected 10 fulmars at Prince Leopold Island $\left(74^{\circ} \mathrm{N}, 90^{\circ} \mathrm{W}\right)$ and 15 fulmars at Cape Searle $\left(67^{\circ} 14^{\prime} \mathrm{N}, 62^{\circ} 28^{\prime} \mathrm{W}\right)$ in 2008 as part of an International Polar Year Project (Provencher et al. 2009). These locations are all within the High Arctic oceanographic zone (Salomonsen 1965).

Most fulmars were collected with a 12-gauge shotgun using steel shot, except for all those taken at Prince Leopold Island and some of those at Cape Vera, which were captured by noose pole on their nest, and then quickly euthanized. In the North Water Polynya study, gizzards and proventriculi were dissected out and then preserved in ethanol or kept frozen, whereas in the other studies, carcasses were frozen soon after collection. All North Water Polynya carcasses were later dissected in a laboratory; 4 (11\%) of these carcasses had no dietary items in either digestive organ, and we did not record whether dietary items were from the proventriculus or gizzard. For Cape Vera fulmars, the mass of the gizzard $( \pm 0.1 \mathrm{~g})$ and proventriculus $( \pm 0.1 \mathrm{~g})$ and the length of the small intestine $( \pm 0.1 \mathrm{~mm})$ were measured $(\mathrm{n}=84)$. For each sample (i.e. proventriculus and gizzard from each fulmar, hereafter referred to as 'stomach'), dietary items were flushed from the proventriculus and gizzard and examined using a dissecting microscope, and identified to the lowest possible taxonomic level. All 119 Cape Vera birds had at least one item in their gizzards, whereas $40(34 \%)$ of them lacked any items in their proventriculi. All fulmars collected at either Cape Searle or Prince Leopold Island had items in their proventriculi or gizzards, but data from both digestive organs were pooled. Bradstreet (1976) also found very few empty stomachs in fulmars that he collected.

The number of amphipods present in each sample was estimated from the number of heads or telsons, whichever was greater. Similarly, numbers of cephalopods were estimated from the number of upper or lower mandibles, or one half of the count of cephalopod eye lenses, whichever was highest. Numbers of polychaete jaws or fish otoliths in each sample were divided by 2 to estimate the numbers of these organisms being represented. Pteropods were identified as whole organisms, and mammal flesh was identified by the presence of hair.

A small $(<2 \mathrm{~g})$ sample of breast muscle collected from most birds was frozen and then shipped to the University of Saskatchewan for stable isotope analysis using standard procedures to determine $\delta^{15} \mathrm{~N}$ and $\delta^{13} \mathrm{C}$ values as outlined in Hobson et al. (2002). Within food webs, relatively higher values of $\delta^{15} \mathrm{~N}$ indicate that an organism had been foraging at a higher trophic level, while lower values of $\delta^{13} \mathrm{C}$ suggest consumption of prey from more pelagic habitats (Hobson \& Welch 1992, Hobson 1993, Hobson et al. 2002).

To determine where fulmars breeding at Cape Vera were foraging, we equipped some breeding birds with satellite transmitters (procedures described in Mallory \& Gilbert 2008). Foraging locations of Cape Vera fulmars have been previously described (Mallory et al. 2008a,b), but we show 2 foraging trips here (Fig. 1) to confirm the relationship between the North Water Polynya and the Cape Vera colony.

Samples were compared on 2 criteria: (a) proportion of stomachs that included at least 1 specimen of a given taxon (\% occurrence) and (b) for certain prey items, mean number of individuals of a given taxon per stomach (mean representation). The percent occurrence is an index of how commonly fulmars consume a particular prey item (i.e. if the \% occurrence is high, then most fulmars eat that item). In contrast, the mean representation provides an index of how many of those prey items are consumed, which can be useful when comparing prey items. The 2 measures also provide insights on prey-specific foraging. For example, in Table 1, for copepods in the NOW (North Water Polynya), the \% occurrence is only $26 \%$, but the mean representation is 61 ; in other words, a few fulmars foraged heavily in copepod swarms, resulting in an overall high proportion of copepods per stomach.

We compared \% occurrence of prey in fulmar stomachs collected at different sampling sites using Fisher's exact test, and calculated $95 \%$ CIs for proportions using Clopper-Pearson procedures (Zar 1984). We used ANOVA (Sex, Breeding stage, Sex $\times$ Breeding stage as main effects) to test for differences in digestive organ size (Tukey-Kramer multiple comparisons test for significant effects). Distributions of hard parts in the proventriculi or gizzards (cephalopod beaks or polychaete jaws) were compared with binomial tests. Spearman rank correlations were used to examine temporal trends in isotopes or organ size through the breeding season. All means are presented $\pm \mathrm{SE}$. 


\section{RESULTS}

\section{Stomach content analysis}

We examined the stomach contents of 179 fulmars to identify dietary items (Table 1). Many prey were well digested, but those that could be identified to family level or lower are listed in Table 2. Of 6825 items found, the most numerically abundant items were crustaceans, specifically copepods and amphipods, but cephalopods were found in the greatest proportion of stomachs $(80 \%)$, although represented only by hard parts (beaks). At Cape Vera, these beaks were usually found in the gizzards (379 of 448 pieces; binomial test, $\mathrm{p}<0.001$ ), although those found in the proventriculi suggested more recent consumption of cephalopods. Similarly, most (86 of 129; p < 0.001) polychaete jaws were in the gizzards. Fish otoliths (almost all Boreogadus saida) were found in 19 to $61 \%$ of the specimens in the 4 sampling locations, depending on collection date.

Across the 4 sampling locations, \% occurrence was similar for fish and crustaceans, with a consistently high occurrence of amphipods, and a general absence of decapods and mysids in the diet of High Arctic fulmars. However, there were a few clear differences among sampling locations, particularly for other prey types: at Cape Vera, \% occurrence of polychaetes ( $41 \%$; $95 \%$ CI: 32 to $50 \%)$ was greater than at other sites (combined, $8 \%$; 3 to $18 \%$; Fisher's exact test, $\mathrm{p}<$ 0.001), while $\%$ occurrence of cephalopod beaks was
$34 \%$ (19 to $52 \%$ ) in North Water Polynya fulmars, but $92 \%$ (86 to $96 \%$ ) at other sites ( $\mathrm{p}<0.001)$. Far fewer fulmars $(4 \% ; 1$ to $9 \%)$ from Cape Vera and Prince Leopold Island contained copepods compared to the other 2 locations $(34 \% ; 21$ to $49 \%$; $p<0.001)$. Pieces of mammal flesh (presumably scavenged seal) were found only in 3 samples from the North Water Polynya (Table 1). Finally, \% occurrence of fragile, soft-bodied prey items (e.g. the pteropod Limacina limacina) was $17 \%$ (6 to $34 \%$ ) in the North Water Polynya sample, but few were found at other sites $(0$ to $2 \%, \mathrm{p}<0.001)$.

There was some evidence of seasonal changes in fulmar diet at Cape Vera, notably between May and other months (Table 1). The mean representation of cephalopods (14.2 \pm 4.1$)$ and fish (1.2 \pm 0.1$)$ in May was higher than at any other month (except for $2.4 \pm 0.4$ fish for non-breeders in July). At the same time, May was the only month when the mean representation of crustaceans was $<1 \mathrm{stomach}^{-1}$. The mean representation of polychaetes more than doubled from May through August (Table 1). The increase in the number of amphipods consumed by fulmars in July was attributable principally to 5 fulmars that had each eaten a large number (142 to 872) of ice-associated amphipods (Ischyrocerus anguipes and Gammarus setosus).

Given the apparent change in diet with time, we could only compare diet of breeders and non-breeders in July (to minimize temporal bias). More non-breeding than breeding fulmars contained fish in July $(\mathrm{p}=$ $0.058)$; otherwise, proportions of various prey in the diet were similar. For fulmars collected in the North

Table 1. Fulmarus glacialis. Frequency and proportional occurrence (in brackets) of prey items recovered from the digestive tract of northern fulmars in High Arctic Canada (note that 'total' for Cape Vera includes 5 birds of unknown breeding status). Proportional occurrence in the sample is defined as the percent of fulmars that contained at least one of these prey items. Mean representation of each prey type can be determined by dividing the frequency by the sample size (e.g. for polychaetes in May at Cape Vera: mean representation is $5 / 21=0.24$ bird $^{-1}$ ). PLI: Prince Leopold Island, NOW: North Water Polynya. Twelve birds from NOW had 19 pieces of plastic (34\%, similar to the findings of Mallory 2008)

\begin{tabular}{|c|c|c|c|c|c|c|c|c|c|c|}
\hline \multirow{4}{*}{$\begin{array}{l}\text { Location } \\
\text { Breeding status } \\
\text { Month } \\
\text { Sample size }\end{array}$} & \multicolumn{6}{|c|}{-Cape Vera } & \multirow{4}{*}{$\begin{array}{c}\text { PLI } \\
\text { Breeders } \\
\text { Jul } \\
10\end{array}$} & \multirow{4}{*}{$\begin{array}{c}\text { Cape Searle } \\
\text { Unknown } \\
\text { Aug } \\
15\end{array}$} & \multirow{4}{*}{$\begin{array}{c}\text { NOW } \\
\text { Unknown } \\
\text { May-Aug } \\
35\end{array}$} & \multirow{4}{*}{$\begin{array}{c}\text { Total } \\
179\end{array}$} \\
\hline & \multicolumn{3}{|c|}{ Breeders } & \multicolumn{2}{|c|}{ Non-breeders } & \multirow[t]{2}{*}{ Total } & & & & \\
\hline & May & Jun & Jul & Jul & Aug & & & & & \\
\hline & $21^{1}$ & 32 & 24 & 28 & 9 & 119 & & & & \\
\hline Prey items & & & & & & & & & & \\
\hline Fish & $26(38)$ & $7(19)$ & $9(33)$ & $40(61)$ & $3(33)$ & $93(37)$ & $22(50)$ & $4(27)$ & $25(43)$ & $144(38)$ \\
\hline Crustaceans & $13(52)$ & $38(50)$ & $1429(42)$ & $370(21)$ & $83(33)$ & $1961(40)$ & $11(60)$ & 929 (53) & $2226(46)$ & 5127 (43) \\
\hline Amphipods & $12(48)$ & $27(47)$ & $1232(42)$ & $370(21)$ & $83(33)$ & $1752(38)$ & $9(50)$ & $4(27)$ & $97(40)$ & $1862(38)$ \\
\hline Mysids & & & & & & & $1(10)$ & & & $1(<1)$ \\
\hline Decapods & $1(5)$ & $1(3)$ & & & & $2(2)$ & & & & $2(1)$ \\
\hline Copepods & & $10(6)$ & $197(8)$ & & & $207(3)$ & $1(10)$ & $923(53)$ & $2137(26)$ & $3268(12)$ \\
\hline Cephalopods & $298(100)$ & $188(100)$ & $78(100)$ & $89(89)$ & 30 (89) & $697(97)$ & $12(70)$ & $19(67)$ & $14(34)$ & $742(80)$ \\
\hline Polychaetes & $5(19)$ & $72(34)$ & $12(46)$ & $18(50)$ & $9(67)$ & $119(41)$ & $1(10)$ & $22(27)$ & & $142(30)$ \\
\hline Gastropods & & & & & & $3(3)$ & & & $598(17)$ & $601(4)$ \\
\hline Insects & & & & & & $6(4)$ & & & $3(9)$ & $9(4)$ \\
\hline Vegetation & & & & & & $15(13)$ & $7(70)$ & $7(47)$ & $3(9)$ & $32(18)$ \\
\hline Mammal & & & & & & & & & $3(9)$ & $3(2)$ \\
\hline Rocks & & & & & & $8(8)$ & $2(20)$ & $7(47)$ & $8(9)$ & $25(12)$ \\
\hline
\end{tabular}


Table 2. Fulmarus glacialis. Prey items identified to genus or species levels from samples removed from the esophagus, proventriculus or gizzard of northern fulmars collected in High Arctic Canada. Bold: associated with sea ice (Bradstreet \& Cross 1982)

\begin{tabular}{|c|c|c|}
\hline $\begin{array}{l}\text { Broad dietary } \\
\text { group }\end{array}$ & Family & $\begin{array}{l}\text { Lowest taxonomic } \\
\text { identification }\end{array}$ \\
\hline Fish & $\begin{array}{l}\text { Gadidae } \\
\text { Macrouridae }\end{array}$ & Boreogadus saida \\
\hline $\begin{array}{r}\text { Crustaceans } \\
\text { Amphipods }\end{array}$ & $\begin{array}{l}\text { Ischyroceridae } \\
\text { Gammaridae } \\
\text { Atylidae } \\
\text { Hyperiidae } \\
\text { Lysianassidae }\end{array}$ & $\begin{array}{l}\text { Ischyrocerus anguipes } \\
\text { Gammarus setosus } \\
\text { Gammarus medusarum } \\
\text { Atylus carinatus } \\
\text { Hyperia galba } \\
\text { Hyperia medusarum } \\
\text { Themisto libellula } \\
\text { Eurythenes gryllus } \\
\text { Onisimus sp. } \\
\text { Anonyx sp. }\end{array}$ \\
\hline Copepods & $\begin{array}{l}\text { Calanidae } \\
\text { Metridiidae } \\
\text { Euchaetidae }\end{array}$ & $\begin{array}{l}\text { Calanus hyperboreus } \\
\text { Calanus glacialis } \\
\text { Metridia longa } \\
\text { Pareuchaeta glacialis }\end{array}$ \\
\hline Cephalopods & $\begin{array}{l}\text { Gonatidae } \\
\text { Cranchiidae }\end{array}$ & Gonatus fabricii \\
\hline $\begin{array}{l}\text { Gastropods } \\
\text { (Pteropods) }\end{array}$ & Limacinidae & Limacina limacina \\
\hline Tunicates & Styelidae & Pelonaia sp. \\
\hline Polychaetes & Nereididae & Nereis sp. \\
\hline
\end{tabular}

Water Polynya, pteropods were only found in stomachs of birds collected in August and September, whereas calanoid copepods were found in birds collected in June and especially July.

\section{Gastrointestinal tract morphology}

Both male and female gastrointestinal tracts of fulmars underwent substantial changes through the breeding season (Fig. 2). Gizzard mass was similar between males and females $\left(F_{1,74}=0.8, \mathrm{p}=0.4\right)$, but differed between some stages of breeding $\left(F_{4,74}=12.3\right.$, $\mathrm{p}<0.001$; interactions terms not significant), being significantly heavier upon arrival at the colony (e.g. early May) than during other stages of breeding except hatching (Tukey-Kramer multiple comparisons tests, $\mathrm{p}<0.05)$. Even by the time of hatching, gizzards of male and female fulmars were still $33 \%$ smaller than at the time of arrival at the colony.

Male and female fulmars had proventriculi of similar mass $\left(F_{1,74}=3.1, \mathrm{p}=0.08\right)$, but proventriculus mass differed between some stages of breeding $\left(F_{4,74}=12.7\right.$, $\mathrm{p}<0.001)$. However, there was a significant interaction between sex and breeding stage $(p=0.04)$, so we ana- lyzed proventriculus mass within each sex. For male fulmars, proventriculus mass differed with breeding stage $\left(F_{4,40}=6.6, \mathrm{p}<0.001\right)$, with proventriculus mass being significantly heavier on arrival at the colony than at other stages except for early incubation (Tukey-Kramer multiple comparisons tests, $\mathrm{p}<0.05$ ). The mass of proventriculi of female fulmars also differed with breeding stage $\left(F_{4,34}=11.7, \mathrm{p}<0.001\right)$, with proventriculus mass being heavier on arrival at the colony than at other stages except for pre-laying (Tukey-Kramer multiple comparisons tests, $\mathrm{p}<0.001$ ). At hatching, male and female fulmar proventriculi were 31 and $39 \%$ smaller than on arrival at the colony, respectively.

Male fulmars had consistently longer small intestines than females $\left(F_{1,74}=20.4, \mathrm{p}<0.001\right)$, which is expected because males are structurally larger than females (Mallory \& Forbes 2005). Intestine length also differed with breeding stage $\left(F_{4,74}=4.8, \mathrm{p}=0.002\right)$. For both sexes, small intestine length increased from arrival at the colony to the date of hatching (males by $22 \%$, Spearman rank correlation $\mathrm{r}_{\mathrm{S} 44}=0.34, \mathrm{p}=0.02$; females by $\left.17 \%, r_{\mathrm{S} 40}=0.49, \mathrm{p}=0.001\right)$.

\section{Stable isotopes}

For 121 fulmars collected between 4 May and 20 July at Cape Vera and the North Water Polynya, mean $\delta^{15} \mathrm{~N}$ was $13.9 \pm 0.08 \%$ ( $\mathrm{SE}$; range 12.6 to $16.3 \%$ ), and mean $\delta^{13} \mathrm{C}$ was $-19.5 \pm 0.05 \%$ o (range -21.2 to $18.6 \%$; Fig. 3). Using data from fulmars collected during the same stage of the breeding season in each study (19 May to 7 July), birds from both locations had similar $\delta^{13} \mathrm{C}$ values (Cape Vera: $-19.6 \pm 0.1 \%$, $\mathrm{n}=52$; North Water Polynya: $-19.6 \pm 0.1 \%, \mathrm{n}=19 ; t_{59}=0.3, \mathrm{p}=0.7$ ), but North Water Polynya fulmars had higher $\delta^{15} \mathrm{~N}$ values (Cape Vera: $13.6 \pm 0.1 \%$, n $=52$; North Water Polynya: $14.1 \pm 0.1 \%$, $\left.\mathrm{n}=19 ; t_{36}=3.2, \mathrm{p}=0.003\right)$. Thus, we analysed for temporal trends in isotopes separately for each location. At Cape Vera, $\delta^{13} \mathrm{C}$ values increased slightly as the breeding season progressed $\left(\mathrm{r}_{\mathrm{S} 102}=0.18, \mathrm{p}=0.08\right)$, while $\delta^{15} \mathrm{~N}$ values increased markedly $\left(\mathrm{r}_{\mathrm{S} 102}=0.69, \mathrm{p}<0.0001 ;\right.$ Fig. 3$)$. In the North Water Polynya, fulmars had lower $\delta^{13} \mathrm{C}$ values through the breeding season $\left(\mathrm{r}_{\mathrm{S} 19}=-0.52, \mathrm{p}=0.02\right)$, but $\delta^{15} \mathrm{~N}$ values increased insignificantly $\left(\mathrm{r}_{\mathrm{S} 19}=0.38, \mathrm{p}=0.1\right)$.

\section{DISCUSSION}

In their review of published data on the diet of the northern fulmar, Phillips et al. (1999, p. 166) stated that the fulmar '... has a very catholic diet, which exhibits much spatial and temporal variation'. Our study confirms 

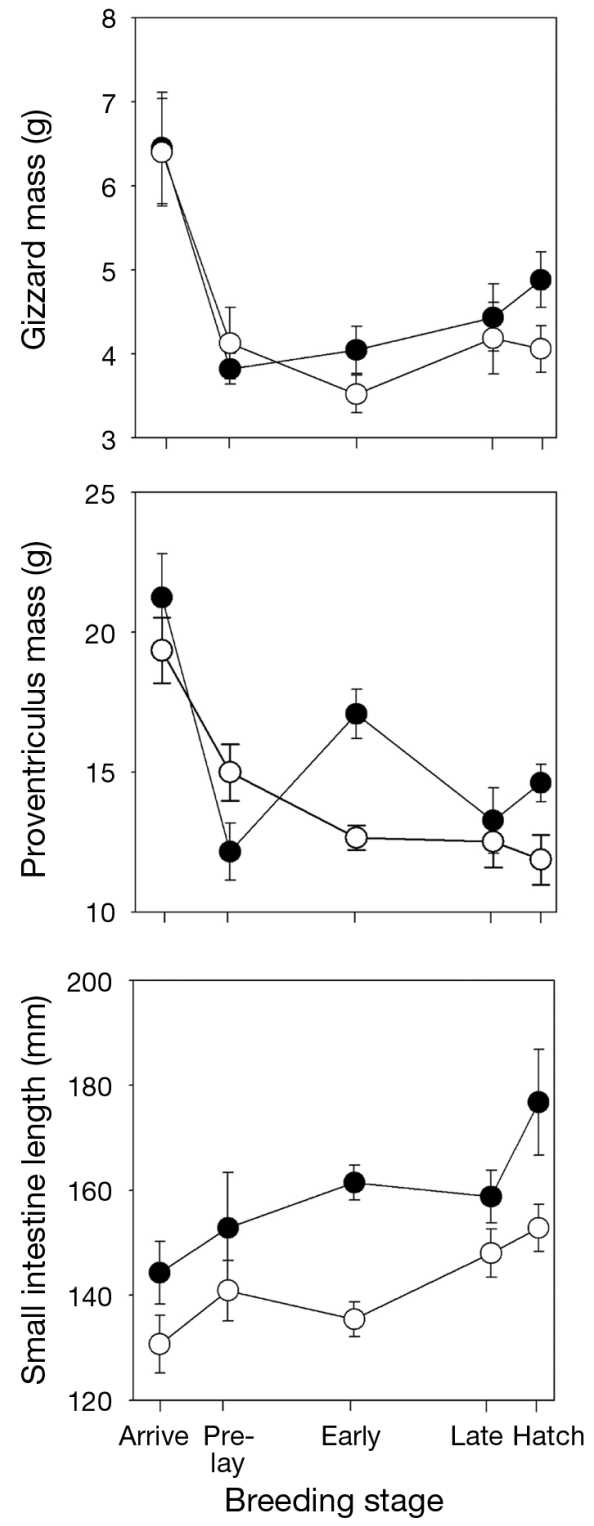

Fig. 2. Fulmarus glacialis. Gizzard mass (g), proventriculus mass $(\mathrm{g})$ and small intestine length $(\mathrm{mm})$ differed between male $(0, \mathrm{n}=44)$ and female $(\mathrm{O}, \mathrm{n}=40)$ northern fulmars collected at different stages through the breeding season

this observation, as well as the classification of fulmars as opportunistic predators (Fisher 1952, Hatch \& Nettleship 1998), even at high latitudes. In all 4 of our study sites, crustaceans (particularly sympagic amphipods and pelagic copepods) were the most abundant prey items consumed, while squid occurred with the highest frequency in stomachs. However, fish may have contributed the most energy to their diet, as suggested by Bradstreet (1976) and Bradstreet \& Cross (1982).

Differential rates of digestion and passage through the digestive tract undoubtedly affect the relative proportions of the different taxa found during stomach
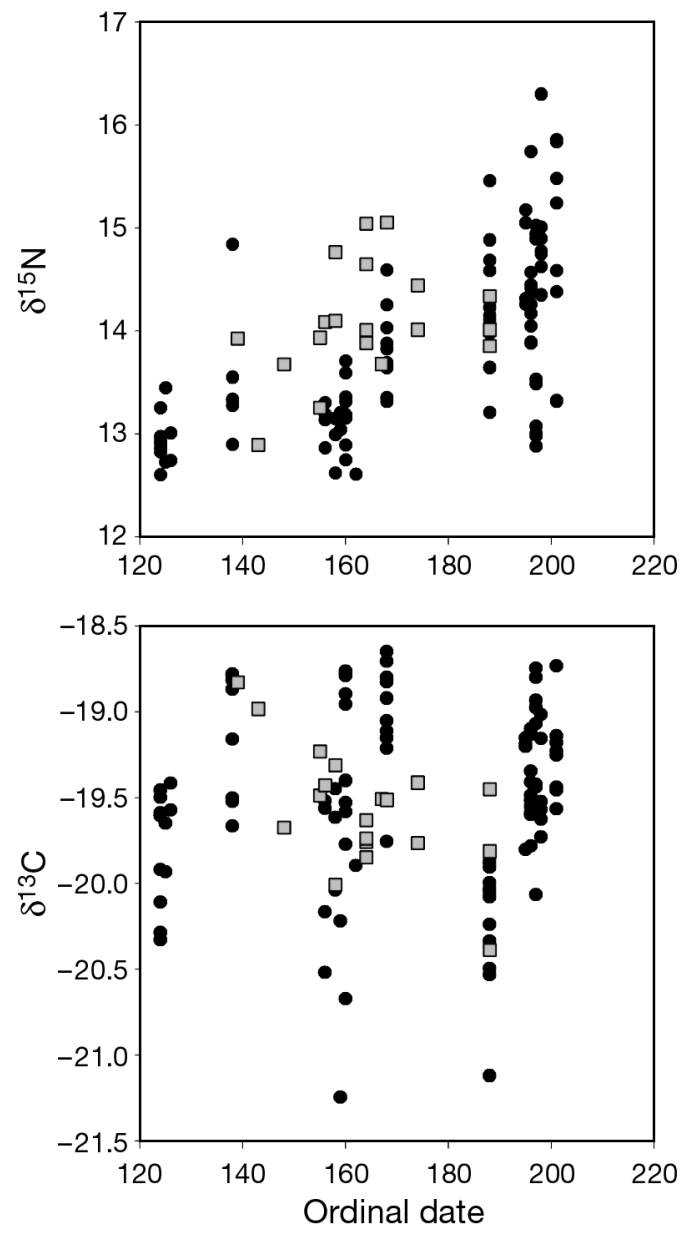

Fig. 3. Fulmarus glacialis. Stable isotopes of nitrogen $\left(\delta^{15} \mathrm{~N}\right)$ increased through the breeding season (Spearman rank correlation $\left.\mathrm{r}_{\mathrm{S} 121}=0.63, \mathrm{p}<0.0001\right)$, whereas those of carbon $\left(\delta^{13} \mathrm{C}\right)$ fluctuated with no consistent pattern $\left(\mathrm{r}_{\mathrm{S} 121}=0.12, \mathrm{p}=\right.$ 0.18). Pooled data from fulmar breast muscle samples from $(\bullet)$ Cape Vera, (ㅁ) North Water Polynya

analysis (e.g. Bradstreet 1976, Gaston \& Noble 1985, Phillips et al. 1999); thus, the types of sampling methods and their biases must be considered when interpreting results of dietary studies (Barrett et al. 2007). In discussing our results below, we acknowledge where these biases may have influenced our observations, and we caution that comparisons of our data to past and future studies should consider both potential biases attributable to methodology, as well as potential effects of annual Arctic ice phenology on prey distribution and availability (e.g. Gaston et al. 2005).

Some of our findings were consistent with earlier investigations of diet in High Arctic fulmars. For example, in a study of fulmar diet similarly based on stomach samples and conducted over 20 yr earlier at Cape Vera ( $\mathrm{n}=233$ fulmars), Byers et al. (2010) found that $90 \%$ of fulmars consumed cephalopods, $41 \%$ ate crus- 
taceans, and $39 \%$ ate polychaetes. These proportions differed by $\leq 7 \%$ from the values we found for invertebrate prey eaten by fulmars at Cape Vera in 2003 to 2005, which suggests long-term stability in the availability of prey in the Hell Gate and North Water Polynya regions of the summer range of Arctic fulmars. Over the same time period, there have been marked changes in the types, availability and abundance of various prey for seabirds in parts of the North Atlantic Ocean, which are presumably the result of anthropogenic stressors (e.g. fisheries, climate-induced oceanographic change; Frederiksen et al. 2004, 2006, Harris et al. 2007, Montevecchi 2007). These food web changes may affect fulmars at southern colonies during the breeding season, and may also affect Arctic fulmars, as these areas may form part of the wintering range for this species (Mallory et al. 2008b).

Despite the overall similarity in invertebrate contributions to the diet of fulmars at Cape Vera over 2 decades, our study also found some novel and notable dietary differences compared to previous investigations on High Arctic fulmars. At Cape Vera, $5 \times$ as many fulmars in our recent samples (44 of 119 birds [37\%], 0.8 fish bird $^{-1}$ ) had fish remains compared to an earlier study at the site, where the same personnel identified and sorted dietary items (16 of 233 [7\% ], 0.1 fish bird ${ }^{-1}$; Byers et al. 2010; Fisher exact test, p < 0.001). This increased fish consumption by fulmars in recent years was also suggested by data from Prince Leopold Island, although our sample size precludes reliable statistical comparison. In July 2008, Prince Leopold Island fulmars averaged 2.2 fish bird $^{-1}$, with 5 of 10 birds (50\%) containing fish. In contrast, during July 1976, 53 fulmars averaged 0.8 fish bird $^{-1}$ (Hatch \& Nettleship 1998), and in the same year in Lancaster Sound, Bradstreet (1976) found only 0.2 fish bird ${ }^{-1}$ in 180 fulmars, with fish in only $29 \%$ of the birds. Even at the ice edge, Bradstreet \& Cross (1982) reported 0.4 fish bird ${ }^{-1}$, with 6 of 31 fulmars (19\%) containing fish. The difference in fish consumption during July may be related to a difference in seasonal availability of prey between these years, which may be affected by the timing of sea ice breakup and thus by access to different food resources (Gaston et al. 2005). Lancaster Sound was relatively free of ice by July 1976, whereas 2008 saw relatively heavy ice cover persisting into July (Environment Canada 2009). Fulmars use ice edges and leads to access sympagic Arctic cod (Hatch \& Nettleship 1998); thus, greater ice cover in 2008 (i.e. more leads and pack ice) might explain part of the higher consumption of fish by fulmar, at least at Prince Leopold Island.

Also at Prince Leopold Island, Hatch \& Nettleship (1998) found that fulmars consumed more fish during the chick-rearing stage (August and September; 1.3 fish bird $^{-1}$ ). In contrast, only $17 \%$ of the fish found in North
Water Polynya fulmar stomachs were from collections in August or September, occurring in $20 \%$ of those birds, whereas $83 \%$ of the fish remains were from birds collected in June and July, occurring in $32 \%$ of those fulmars. Unfortunately, we did not sample known breeding birds very late into the breeding season at Cape Vera, but our data did not suggest a significant increase in fish consumption in August samples (0.3 to 0.4 fish bird $^{-1}$ at Cape Vera, Cape Searle and the North Water Polynya). Phillips et al. (1999), studying the diet of fulmars near Disko Island, Greenland, recorded a similar proportion of birds consuming fish $(38 \%)$, but these were mostly capelin Mallotus villosus. Like our study, they did not observe an increase in fish consumption as the breeding season progressed (in fact, fulmars shifted to crustaceans and pteropods later in the breeding season).

Overall, we found that High Arctic fulmars consumed a low diversity of fish, with far fewer species than are available to fulmars farther south in the North Atlantic or Pacific (Furness \& Todd 1984, Camphuysen \& Garthe 1997, Hatch \& Nettleship 1998, Garthe et al. 2004, Wang et al. 2009).

Interpreting the contribution of squid to fulmar diets is challenging because squid soft tissues are rarely found in fulmar stomachs or regurgitations, although squid beaks (and eye lenses) are the most frequently found dietary remains and may be retained in fulmar stomachs for months (Furness et al. 1984). Nevertheless, our results support those of the broader survey by Phillips et al. (1999) who showed that \% occurrence of squid in fulmar samples from Arctic waters generally exceeds $50 \%$, whereas samples from southern Iceland and the northern UK contain very few squid. Thus, the available evidence strongly suggests that Arctic fulmars consume more squid than their Boreal conspecifics during migration and the breeding season.

Like cephalopods, polychaetes also leave chitinous remains (jaws) when digested. We found polychaete remains in $41 \%$ of the fulmars at Cape Vera, but occurrence was lower in May than in the latter months of the breeding season. Presumably, this temporal pattern is attributable to the availability of the worms at the surface; Nereis are more common at the surface when spawning in the warmer summer waters (Phillips et al. 1999). Arctic fulmars could be ingesting polychaetes directly, or could be getting their remains secondarily by consuming fish that had eaten polychaetes; our data do not allow us to distinguish between these possibilities. Lydersen et al. (1989) found polychaete remains in $82 \%$ of fulmars collected near Svalbard in September, and Belopol'skii (1957), Mehlum \& Gabrielsen (1993) and Phillips et al. (1999) also found polychaetes to be a common component of fulmar diets in the High Arctic. 
Several studies have noted the importance of 'gelatinous' prey to fulmars, particularly jellyfish and pteropods (Harrison 1984, Hobson \& Welch 1992, Camphuysen \& van Franeker 1996, 1997). Byers et al. (2010) noted abundant pteropods in the waters near Cape Vera, but found none in the diet of fulmars from that colony, and we did not record any during recent sampling. Pteropods were common prey of fulmars collected at sea in Lancaster Sound in 1976 (21 items $\operatorname{bird}^{-1}$; Bradstreet 1976), but were not observed in the diet of birds at the Prince Leopold Island colony in the same year (Hatch \& Nettleship 1998). In our study, pteropods were only recorded in the stomachs of fulmars collected at sea in the North Water Polynya, which strongly suggests that these soft-bodied prey are digested quickly by fulmars in transit to their breeding colonies - a potential bias due to sampling methods (Barrett et al. 2007). Thus, colony-based investigations probably underestimate the contribution of soft-bodied prey to fulmar diets.

It is clear that amphipods and copepods are key components of the diet of High Arctic fulmars (Bradstreet 1976, Hatch \& Nettleship 1998, Byers et al. 2010; this study). Fulmars opportunistically capture sympagic and other amphipods, occasionally resulting in tens of amphipods per fulmar stomach. However, fulmars exploit and gorge themselves on copepod swarms at the sea surface, to the point where a bird can have difficulty departing from the water surface when approached by boat (Byers et al. 2010). Hundreds of copepods can be found in an individual fulmar stomach (Table 1). In our study, fulmars collected at Cape Vera and Prince Leopold Island (i.e. at colonies) had an amphipod:copepod ratio in their diet of 8.5:1 (Table 1), whereas for the North Water Polynya and Cape Searle samples shot at sea, the ratio was only 0.03:1 (283× lower). The at-sea ratio is similar to the colony-based ratio found at Prince Leopold Island in 1976 (0.08:1; Hatch \& Nettleship 1998) or Cape Vera in the early 1980s (0.16:1; Byers et al. 2010). These differences in ratios suggest some bias in the most recent, colonybased samples. We speculate that copepod swarms were relatively distant from Cape Vera or Prince Leopold Island for the recent samples, and thus that consumed copepods were well digested when the birds returned and were shot.

\section{Gastrointestinal tract morphology}

Upon their first arrival at the breeding colony in May, fulmars initiate a $2 \mathrm{wk}$ fast (Mallory \& Forbes 2008), at which time their gizzards decrease markedly in mass and their intestines are relatively short. For the following $2 \mathrm{mo}$, their digestive organs increase in size, mirroring the pattern exhibited by High Arctic red knots (Calidris canutus; Morrison \& Hobson 2004, Morrison 2006). When birds use their digestive organs more, or when they consume prey that requires more work to digest, those organs increase in size (length or mass; Ankney 1977, Drobney 1984, Battley et al. 2000, van Gils et al. 2005). The partial recovery of fulmar digestive apparatus probably reflects a shift from using stored (endogenous) energy reserves and minimizing costs of maintaining organs that are unnecessary for migration or early season survival. An increase in feeding, or possibly a switch to other prey types, leads to rebuilding of the digestive tract for foraging to meet energy requirements for incubation and to acquire exogenous reserves for self-maintenance.

\section{Stable isotopes}

Muscle $\delta^{15} \mathrm{~N}$ and $\delta^{13} \mathrm{C}$ values for fulmars foraging at $\geq 76^{\circ} \mathrm{N}$ in our study were similar to values found for fulmars elsewhere across their range during the breeding season (Hobson \& Welch 1992, Hobson et al. 1994, Thompson \& Furness 1995, Dahl et al. 2003), which suggests that fulmars occupy an intermediate position in the High Arctic food web. This is consistent with previous isotopic modeling in the High Arctic (Hobson 1993), where it was proposed that fulmar diet might consist of roughly $66 \%$ amphipods and $33 \%$ fish in the summer, based on a simple model. However, fulmars are opportunistic predators, and as such, their varied diet poses problems for interpreting contributions of different prey to their diet, based on isotopes (Hobson 1993). Thompson \& Furness (1995), using isotopes in primary feathers, reported a significant decrease in the trophic level at which St. Kilda fulmars fed during the winter compared to the summer. In our study, fulmars arrived at the colony with low $\delta^{15} \mathrm{~N}$ values, but these increased towards the date of hatching in samples from Cape Vera and the North Water. As we analysed stable isotope values in muscles, values reflected the diet from the previous month because the half-life for muscle tissue turnover for a $700 \mathrm{~g}$ bird is $11.5 \mathrm{~d}$ (Hobson 1993). Consequently, these values represent diets from April through June (i.e. northward migration to mid-incubation). Moreover, because High Arctic fulmars undertake a fast after arriving at the colony (Mallory \& Forbes 2008), some of the increase in $\delta^{15} \mathrm{~N}$ could be attributable to nutritional stress and consequent catabolism of muscle tissue, as found in geese (Hobson et al. 1993). Nonetheless, High Arctic fulmars overwinter across the North Atlantic like fulmars from the UK (Fisher 1952, Lyngs 2003, Mallory et al. 2008b), and probably forage on similar pelagic food. Thus, there appears to be a consistent pattern in fulmar diets at dis- 
parate sites across the North Atlantic population, with birds feeding at higher trophic levels during the breeding season, and then at lower trophic levels during the winter (although fulmars probably also feed behind fishing boats in the winter; Fisher 1952, Hatch \& Nettleship 1998).

The 'natural' winter diet of fulmars, especially fulmars known to breed in the High Arctic, remains largely unknown. Camphuysen \& Garthe (1997) noted that fulmars tended to leave the North Sea and reduced their exploitation of fisheries vessels in the North Sea during the winter. However, near the Barents Sea, Erikstad (1990) found that wintering fulmars consumed several species of fish, which presumably are at relatively high trophic levels. Juvenile Gonatus fabricii squid are well represented in the diet of Arctic fulmars, and these squid appear to feed at a relatively lower trophic level $\left(\delta^{15} \mathrm{~N}\right.$ : 9.2 to $9.7 \%$; Hooker et al. 2001). A regional dietary or isotopic assessment of fulmars during the winter would shed much light on their energetics and ecological needs, as advocated by Hobson (1993).

Trends in $\delta^{13} \mathrm{C}$ values through the breeding season differed between fulmars collected at Cape Vera and the North Water Polynya, and were generally more variable than $\delta^{15} \mathrm{~N}$ patterns. We speculate that this was due to differences in the microhabitats where fulmars were feeding annually, which is partly attributable to patterns of ice breakup. For example, the dietary data suggested that at least some fulmars were feeding along ice edges in July (consuming many sympagic amphipods), whereas others were concurrently feeding on pelagic copepods. Prey from these habitats exhibit quite different $\delta^{13} \mathrm{C}$ values (Hobson et al. 2002).

\section{Conclusion}

Even within the High Arctic oceanographic zone, northern fulmars exhibited regional variation in their diet during the breeding season, consistent with the opportunistic foraging behavior noted in this petrel by Fisher (1952) and Hatch \& Nettleship (1998). Diet and stable isotope analyses pointed to a seasonal shift in fulmar diet in May (i.e. first arrival at the breeding colony), and thus effectively separated northward migration from the breeding season. We found generally good consistency between proportions of various invertebrate prey in recent fulmar diets and proportions from the 1970s and 1980s, suggesting decadal stability in local High Arctic food webs. However, we observed an increase in the proportion of fish consumed in recent samples, which could be related to differences in food availability due to patterns and timing of sea ice breakup (Gaston et al. 2005). A long-term pattern of earlier ice breakup in migration and feeding areas (ACIA 2005) will alter the timing and availability of prey for fulmars, perhaps relaxing the constraints on reproduction presently experienced by fulmars in the High Arctic (Mallory \& Forbes 2007). Given that High Arctic northern fulmars appear to arrive at their colonies with larger, stored endogenous nutrient reserves, undertake a longer pre-laying exodus, and often have longer incubation recesses compared to Boreal fulmars (Mallory \& Forbes 2007, 2008, Mallory et al. 2008a), 2 key dietary questions remain unresolved for this species: (1) Do higher foraging effort, different prey selection, or both, allow High Arctic fulmars to store more migratory and pre-laying energetic reserves than Boreal and Low Arctic fulmars? (2) When and where are fulmars ingesting cephalopods, and is this taxon a key group in the nutrition of High Arctic fulmars early in the breeding season?

Acknowledgements. This paper resulted from data collected during several projects, and thus we are indebted to many different people. From the North Water Polynya Project, we thank the crew of the Coast Guard vessels 'Louis St. Laurent' and 'Pierre Radisson' for assistance, as well as numerous scientists and assistants on board who helped with collections (P. Akeeagok, D. Andriashek, W. Calvert, J. Carlson, A. Fisk, M. Holst, N. Lunn, I. Stirling, J. Zamon). From the Cape Vera, Prince Leopold Island and Cape Searle projects (the latter 2 being International Polar Year [IPY] projects), we thank the numerous assistants who helped with fieldwork, particularly J. Akearok, A. Fontaine, G. Gilchrist, K. O'Donovan, I. Storm, S. Smith, and J. Szucs. Stable isotope measurements were conducted at accredited laboratories at the Department of Soil Science, University of Saskatchewan, and at SINLAB, University of New Brunswick. K. Wilcox of the Long Point Waterfowl and Wetlands Research Fund performed the dissections and measurements of gastrointestinal tracts. J. Dower provided space and resources at the University of Victoria for the dissection of the Prince Leopold Island and Cape Searle birds through his NSERC Strategic grant. All collections were made under appropriate territorial and federal research and land use permits in Canada. Financial and logistic support were provided by the National Science Foundation Office of Polar Programs grant number OPP 9725071, as well as Environment Canada (CWS, NEI), Natural Resources Canada (PCSP), and Indian and Northern Affairs Canada (NCP, IPY).

\section{LITERATURE CITED}

ACIA (2005) Impacts of a warming Arctic: Arctic climate impact assessment. Cambridge University Press, p 140

Ankney CD (1977) Feeding and digestive organ size in breeding lesser snow geese. Auk 94:275-282

Barrett RT, Camphuysen CJ, Anker-Nilssen T, Chardine JW and others (2007) Diet studies of seabirds: a review and recommendations. ICES J Mar Sci 64:1675-1691

Battley PF, Piersma T, Dietz MW, Tang S, Dekinga A, Hulsman K (2000) Empirical evidence for differential organ reductions during trans-oceanic bird flight. Proc Biol Sci 267:191-195

Belopol'skii LO (1957) Ecology of sea colony birds of the Bar- 
ents Sea. Israel Prog Sci Trans, Jerusalem, p 346

Bradstreet M (1976) Summer feeding ecology of seabirds in eastern Lancaster Sound. LGL Limited, Environmental Research Assoc, Toronto, p 187

Bradstreet MSW, Cross WE (1982) Trophic relationships at High Arctic ice edges. Arctic 35:1-12

Brown RGB, Nettleship DN (1981) The biological significance of polynyas to Arctic colonial seabirds. In: Stirling I, Cleator H (eds) Polynyas in the Canadian Arctic. Can Wildl Serv Occas Pap No 45:59-65

Byers T, Smith A, Mallory ML (2010) Diet of black guillemots and northern fulmars breeding beside a High Arctic polynya. Polar Biol 33:457-467

Camphuysen CJ, Garthe S (1997) An evaluation of the distribution and scavenging habits of northern fulmars (Fulmarus glacialis) in the North Sea. ICES J Mar Sci 54:$654-683$

Camphuysen CJ, van Franeker JA (1996) Jellyfish and fishery waste as food sources of northern fulmars Fulmarus glacialis feeding around St. Kilda. Sula 10:143-150

Camphuysen CJ, van Franeker JA (1997) Notes on the diet of northern fulmars Fulmarus glacialis from Bjørnøya (Bear Island). Sula 11:1-10

Dahl TM, Falk-Petersen S, Gabrielsen GW, Sargent JR, Hop H, Millar RM (2003) Lipids and stable isotopes in common eider, black-legged kittiwake and northern fulmar: a trophic study from an Arctic fjord. Mar Ecol Prog Ser 256: 257-269

Drobney RD (1984) Effect of diet on the visceral morphology of wood ducks. Auk 101:93-98

Environment Canada (2009) Canadian ice service - ice graph version 1.0. http://ice-glaces.ec.gc.ca/IceGraph/IceGraph Display-GraphdesGlacesDisplay.jsf (accessed 1 January 2010)

Erikstad K (1990) Winter diets of four seabird species in the Barents Sea after a crash in the capelin stock. Polar Biol 10:619-627

Fisher J (1952) The fulmar. Collins, London

> Frederiksen M, Wanless S, Harris MP, Rothery P, Wilson LJ (2004) The role of industrial fisheries and oceanographic change in the decline of North Sea black-legged kittiwakes. J Appl Ecol 41:1129-1139

Frederiksen M, Edwards M, Richardson AJ, Halliday NC, Wanless S (2006) From plankton to top predators: bottomup control of a marine food web across four trophic levels. J Anim Ecol 75:1259-1268

Furness RW, Todd CM (1984) Diets and feeding of fulmars Fulmarus glacialis during the breeding season: a comparison between St. Kilda and Shetland colonies. Ibis 126: 379-387

Furness BL, Laugksch RC, Duffy DC (1984) Cephalopod beaks and studies of seabird diets. Auk 101:619-620

> Garthe S, Montevecchi WA, Ojowski U, Stenhouse IJ (2004) Diets of northern fulmar (Fulmarus glacialis) chicks in the northwest Atlantic Ocean. Polar Biol 27:277-280

Gaston AJ, Noble DG (1985) The diet of thick-billed murres (Uria lomvia) in west Hudson Strait and northeast Hudson Bay. Can J Zool 63:1148-1160

Gaston AJ, Woo K, Hipfner JM (2003) Trends in forage fish populations in northern Hudson Bay since 1981, as determined from the diet of nestling thick-billed murres Uria lomvia. Arctic 56:227-233

Gaston AJ, Gilchrist HG, Mallory ML (2005) Variation in ice conditions has strong effects on the breeding of marine birds at Prince Leopold Island, Nunavut. Ecography 28: 331-344

Hamer KC, Thompson DR, Gray CM (1997) Spatial variation in the feeding ecology, foraging ranges, and breeding energetics of northern fulmars in the north-east Atlantic Ocean. ICES J Mar Sci 54:645-653

> Harris MP, Beare D, Toresen R, Nøttestad L and others (2007) A major increase in snake pipefish (Entelurus aequoreus) in northern European seas since 2003: potential implications for seabird breeding success. Mar Biol 151:973-983

Harrison NM (1984) Predation on jellyfish and their associates by seabirds. Limnol Oceanogr 29:1335-1337

Hatch SA, Nettleship DN (1998) Northern fulmar (Fulmarus glacialis). In: Poole A, Gill F (eds) The birds of North America, No. 361. The Birds of North America, Philadelphia, PA

> Hobson KA (1993) Trophic relationships among high Arctic seabirds: insights from tissue-dependent stable-isotope models. Mar Ecol Prog Ser 95:7-18

Hobson KA, Welch HE (1992) Determination of trophic relationships within a high Arctic marine food web using $\delta^{13} \mathrm{C}$ and $\delta^{15} \mathrm{~N}$ analysis. Mar Ecol Prog Ser 84:9-18

> Hobson KA, Alisauskas RT, Clark RG (1993) Stable nitrogen isotope enrichment in avian tissues due to fasting and nutritional stress: implications for isotopic analyses of diet. Condor 95:388-394

Hobson KA, Piatt JF, Pitocchelli J (1994) Using stable isotopes to determine seabird trophic relationships. J Anim Ecol 63:786-798

> Hobson KA, Fisk A, Karnovsky N, Holst M, Gagnon JM, Fortier M (2002) A stable isotope $\left(\delta^{13} \mathrm{C}, \delta^{15} \mathrm{~N}\right)$ model for the North Water food web: implications for evaluating trophodynamics and the flow of energy and contaminants. DeepSea Res II 49:5131-5150

> Hooker SK, Iverson SJ, Ostrom P, Smith SC (2001) Diet of northern bottlenose whales inferred from fatty-acid and stable-isotope analyses of biopsy samples. Can J Zool 79:1442-1454

Karnovsky NJ, Kwaśniewski S, Węsławski JM, Walkusz W, Beszczyńska-Möller A (2003) Foraging behavior of little auks in a heterogeneous environment. Mar Ecol Prog Ser 253:289-303

Karnovsky NJ, Hobson KA, Iverson S, Hunt GL Jr (2008) Seasonal changes in diets of seabirds in the North Water Polynya: a multiple-indicator approach. Mar Ecol Prog Ser 357:291-299

Lydersen C, Gjertz I, Weslawski JM (1989) Stomach contents of autumn-feeding marine vertebrates from Hornsund, Svalbard. Polar Rec (Gr Brit) 25:107-114

Lyngs P (2003) Migration and winter ranges of birds in Greenland. Dansk Ornitol Foren Tidssk 97:1-167

Mallory ML (2006) The northern fulmar (Fulmarus glacialis) in Arctic Canada: ecology, threats, and what it tells us about marine environmental conditions. Environ Rev 14: $187-216$

Mallory ML (2008) Marine plastic debris in northern fulmars from the Canadian High Arctic. Mar Pollut Bull 56: 1501-1504

Mallory ML, Fontaine AJ (2004) Key marine habitat sites for migratory birds in Nunavut and the Northwest Territories. Can Wildl Serv Occas Pap No 109

Mallory ML, Forbes MR (2005) Sex discrimination and measurement bias in northern fulmars (Fulmarus glacialis) from the Canadian Arctic. Ardea 93:25-36

> Mallory ML, Forbes MR (2007) Does sea ice constrain the breeding schedules of High Arctic northern fulmars? Condor 109:894-906

Mallory ML, Forbes MR (2008) Costly pre-laying behaviors and physiological expenditures by northern fulmars in the high Arctic. Ecoscience 15:545-554 
Mallory ML, Gilbert CD (2008) Leg-loop harness design for attaching external transmitters to seabirds. Mar Ornithol 36:183-188

Mallory ML, Forbes MR, Ankney CD, Alisauskas RT (2008a) Nutrient dynamics and constraints on the pre-laying exodus of high Arctic northern fulmars. Aquat Biol 4:211-223

Mallory ML, Akearok J, Edwards DB, O'Donovan K, Gilbert CD (2008b) Autumn migration and wintering of northern fulmars (Fulmarus glacialis) from the Canadian High Arctic. Polar Biol 31:745-750

Mehlum F, Gabrielsen GW (1993) The diet of high-arctic seabirds in coastal and ice-covered pelagic areas near the Svalbard archipelago. Polar Res 12:1-20

Montevecchi WA (2007) Binary dietary responses of northern gannets Sula bassana indicate changing food web and oceanographic conditions. Mar Ecol Prog Ser 352:213-220

Morrison RIG (2006) Body transformations, condition, and survival in red knots Calidris canutus traveling to breed at Alert, Ellesmere Island, Canada. Ardea 94:607-618

Morrison RIG, Hobson KA (2004) Use of body stores in shorebirds after arrival on High-Arctic breeding grounds. Auk 121:333-344

Phillips RA, Petersen MK, Lilliendahl K, Solmundsson J, Hamer KC, Camphuysen CJ, Zonfrillo B (1999) Diet of the northern fulmar Fulmarus glacialis: reliance on commercial fisheries? Mar Biol 135:159-170

Editorial responsibility: William Sydeman,

Petaluma, California, USA
Provencher JF, Gaston AJ, Mallory ML (2009) Evidence for increased ingestion of plastics by northern fulmars (Fulmarus glacialis) in the Canadian Arctic. Mar Pollut Bull 58:1092-1095

Salomonsen F (1965) The geographical variation of the fulmar (Fulmarus glacialis) and the zones of marine environment in the North Atlantic. Auk 82:327-355

Stirling I (1997) The importance of polynyas, ice edges and leads to marine mammals and birds. J Mar Syst 10:9-21

Thompson DR, Furness RW (1995) Stable-isotope ratios of carbon and nitrogen in feathers indicate seasonal dietary shifts in northern fulmars. Auk 112:493-498

> van Gils JA, Battley PF, Piersma T, Drent R (2005) Reinterpretation of gizzard sizes of red knots world-wide emphasizes overriding importance of prey quality at migratory stopover sites. Proc Biol Sci 272:2609-2618

Wang SW, Iverson SJ, Springer AM, Hatch SA (2009) Spatial and temporal diet segregation in northern fulmars Fulmarus glacialis breeding in Alaska: insights from fatty acid signatures. Mar Ecol Prog Ser 377:299-307

Woo KJ, Elliott KH, Davidson M, Gaston AJ, Davoren GK (2008) Individual specialization in diet by a generalist marine predator reflects specialization in foraging behaviour. J Anim Ecol. doi:10.1111/j.1365-2656.2008.01429.x

Zar JH (1984) Biostatistical analysis, 2nd edn. Prentice Hall, Englewood Cliffs, NJ, p 130

Submitted: January 18, 2010; Accepted: Jul 22, 2010

Proofs received from author(s): August 17, 2010 